Tohoku J. Exp. Med., 2009, 219, 33-37

\title{
The Deletion Polymorphism of the Angiotensin-Converting Enzyme Gene Is Associated with Acute Aortic Dissection
}

\author{
Nihat Kalay, ${ }^{1}$ Okay Caglayan, ${ }^{2}$ Hasan Akkaya, ${ }^{1}$ Ibrahim Ozdogru, ${ }^{1}$ Ali Dogan, ${ }^{1}$ \\ Mehmet Tugrul Inanc, ${ }^{1}$ Mehmet Gungor Kaya, ${ }^{1}$ Ali Ergin, ${ }^{1}$ Ramazan Topsakal, ${ }^{1}$ \\ Davran Çiçek, ${ }^{3}$ Namık Kemal Eryol, ${ }^{1}$ Kutay Taşdemir, ${ }^{4}$ Abdurrahman Oguzhan ${ }^{1}$ \\ and Munis Dundar ${ }^{2}$
}

${ }^{1}$ Department of Cardiology, Erciyes University, Medical Faculty, Kayseri, Turkey
${ }^{2}$ Department of Medical Genetic, Erciyes University, Medical Faculty, Kayseri, Turkey
${ }^{3}$ Başkent University, School of Medicine, Department of Cardiology, Antalya, Turkey
${ }^{4}$ Department of Cardiovascular Surgery, Erciyes University, Medical Faculty, Kayseri, Turkey

Aortic dissection (AD) is a disease characterized by tear of the aortic intimal layer and separation of the arterial wall. Some risk factor such as hypertension and Marfan syndrome is well known in AD. However, the role of genetic factors in $A D$ is largely unknown. Insertion/deletion (I/D) polymorphism of the angiotensin-converting enzyme (ACE) gene is associated with cardiovascular diseases; patients with D allele have higher serum and tissue ACE levels. We investigated the relationship between the I/D polymorphism of the ACE gene and non-syndromic acute AD. Sixteen patients diagnosed with AD were included in the study (mean age: $60.1 \pm 6.2$ years). The diagnosis was established by clinical evaluation and imaging techniques. The control group consisted of 22 age-matched patients without AD $(60.9 \pm 7.3$ years), who suffered from chest pain. Incidence of hypertension was similar in dissection and control groups (62\% vs. $59 \%$ ). The I/D polymorphism was investigated in both groups by PCR analysis. Dissection types according to the DeBakey classification were identified as type 1 (proximal + distal) in 7 patients (43\%), type 2 (proximal) in 5 patients (31\%), and type 3 (distal) in 4 patients (25\%). The D/D and $\mathrm{D} / \mathrm{l}$ polymorphisms are present in 13 and $3 \mathrm{AD}$ patients, respectively. None of patients with $A D$ have the II polymorphism. The frequencies of the $D$ allele $(D D+I D)$ are significantly higher in dissection group than control $(100 \%$ vs. $68 \%, P<0001)$. These results indicate that the D allele of ACE gene is a risk factor for AD. - Aortic dissection; Angiotensin Converting Enzime; Gene polymorphism; Chest pain; Hypertension.

Tohoku J. Exp. Med., 2009, 219 (1), 33-37. C 2009 Tohoku University Medical Press

Aortic dissection (AD) is a relatively uncommon vascular disease characterized with a tear in the intimal layer of the aorta, hematoma formation and separation of the arterial wall. It is associated with high degree of mortality, despite current diagnostic and treatment techniques (Hagan et al. 2000). The cause of aortic dissection is multifactorial, with genetic, environmental, and physiologic factors (Erbel et al. 2001; Khan and Nair 2002). A small proportion of cases of $\mathrm{AD}$ are associated with inherited diseases and syndromes, such as Marfan syndrome (Caglayan and Dundar 2009). Although numerous studies have revealed genetic factors in Marfan syndromes, the specific genetic factor associated with non-syndromic acute AD is unknown (Biddinger et al. 1982; De Bakey et al. 1982; Boileau et al. 2005; Robinson et al. 2006).

The renin-angiotensin system is a complex regulator of blood pressure, cardiovascular remodeling and vascular tone. It is composed of angiotensinogen, angiotensin-con- verting enzyme (ACE), angiotensin II and various receptors (Erdos 1990). Angiotensin-converting enzyme is an important enzyme in the renin-angiotensin system and has considerable impact on cardiovascular structure and function (Hubert et al. 1991; Ehlers and Riordan 1989). The ACE gene, located on chromosome 17 , has been cloned and is characterized in humans by a major insertion (I)/deletion (D) polymorphism consisting of the presence or absence of a 287-bp alu repeat sequence within intron 16.

Previous studies have shown the potential genetic risk of the ACE genotype in cardiovascular disease and hypertension (Lindpaintner et al. 1995; Matsubara 2000; Uemura et al. 2000). Cardiovascular risk increases in patients with $\mathrm{D}$ allele (Cambien et al. 1992). The cause of increased cardivascular risk may be associated with increase in plasma ACE activity or level. The polymorphism of ACE gene is associated with serum and tissue ACE level (Rigat et al. 1990; Esther et al. 1997). Higher circulating ACE activity

Received April 15, 2009; revision accepted for publication July 16, 2009. doi:10.1620/tjem.219.33

Correspondence: Nihat Kalay, M.D., FESC, Department of Cardiology, Erciyes University Medical Faculty, Kayseri, Turkey.

e-mail: nihatkalay@hotmail.com 
has been measured presence of the D allele and DD polymorphism (Tsutaya et al. 1997; Jalil et al. 1999).

While patients with DD polymorphism have the highest serum ACE activity, patients with II polymorphism have the lowest serum ACE activity (Agerholm-Larsen et al. 2000).

Some risk factors for AD such as systemic hypertension, the Marfan syndrom and bicuspid aortic valve are well known (Larson and Edwards 1984). However, the relation between the ACE gene D/I polymorphism and non-syndromic $\mathrm{AD}$ is unclear. In the current study, we investigated whether the $\mathrm{D} / \mathrm{I}$ polymorphism of the ACE gene is a predisposing factor for $\mathrm{AD}$ in the absence of a known genetic syndrome.

\section{Materials and Methods}

Patients

In present study, ACE gene polymorphism was prospectively investigated in patients with acute AD. Patients diagnosed with acute $\mathrm{AD}$ in the emergency and cardiology department of the Erciyes University Medical School between September 2005 and October 2007 were enrolled in the study. Patients with iatrogenic, traumatic, or syndromic aortic dissections were excluded.

Age, gender, body mass index, and rates of diabetes mellitus and hypertension were recorded. Blood pressure was measured in all patients twice at both arms. Hypertension was defined as blood pressure above systolic $\geq 140$ and diastolic $\geq 90 \mathrm{mmHg}$ (World Health Organization, International Society of Hypertension Writing Group 2003). Diabetes mellitus was defined as a fasting blood glucose level of $127 \mathrm{mg} / \mathrm{dl}$ or greater, or a clinical diagnosis of diabetes with use of oral antidiabetic or insulin treatment. Aortic dissection was defined as the presence of any dissection in aortic arch with presentation within 14 days of symptom onset. The diagnosis of acute AD was established according to clinical evaluation and imaging techniques (chest radiography, transthoracic echocardiography, transesophageal echocardiography, computed tomography) (Erbel et al. 2001). The AD group was composed of 16 patients with confirmed acute AD. In similar population with $\mathrm{AD}, 22$ well-matched patients who were admitted to our cardiology department due to any chest pain of an origin other than aortic dissection was included the control group.

All patients with suspected AD were evaluated with transthorasic and multiplanar transesophageal echocardiography using the Wingmed System V echocardiography device (General Electric, Vingmed System 5, Horten, Norway). Helical Computed tomography (Shimadzu, CT/SCT-7000XT, Kyoto, Japan) was performed on 14 patients using non-ionic contract agent (100 mL Omnipaque, Nycomed, Amersham Health, Cork, Ireland). The diagnosis of AD was based on the demonstration of an intimal flap and true and false lumen with imaging techniques. Aortic dissections were classified into three types according to their anatomic location using De Bakey classification (De Bakey et al. 1965); namely, type 1 involves ascending and descending aorta, Type 2 involves only ascending aorta, and Type 3 involves only descending aorta.

\section{D/I Polymorphism on Intron 16 of ACE Gene}

Venous blood was collected in $6 \mathrm{~mL}$ EDTA tubes, and genomic DNA was isolated using Nucleospin Blood kit (NucleoSpin Blood, Macherey-nagel GmbH\&Co, Germany) and stored at $4^{\circ} \mathrm{C}$. Detection of the ACE gene polymorphism was performed using PCR methodology according to previously published protocols (Rigat et al. 1990; Lindpaintner et al. 1995) using primers 5'-GCC CTG CAG GTG TCT GCA GCA TGT-3' and 5'-GGA TGG CTC TCC CCG CCT TGT CTC-3'. Cycling conditions were an initial denaturation at $95^{\circ} \mathrm{C}$ for 4 min, followed by 35 cycles of $45 \mathrm{~s}$ at $94^{\circ} \mathrm{C}, 60 \mathrm{~s}$ at $58^{\circ} \mathrm{C}$, and $72^{\circ} \mathrm{C}$ for $60 \mathrm{~s}$. PCR was carried out in a reaction mixture containing $20 \mathrm{pmol}$ of each primer, $2.5 \mathrm{mM} \mathrm{MgCl} 2,0.2 \mathrm{mM}$ of each dNTP, and $0.5 \mathrm{U}$ of Taq DNA polymerase. The resulting PCR products were separated on $2 \%$ agarose gels with ethidium bromide staining and visualized under ultraviolet light. The presence of D allele (319 bp fragment) and I allele (597 bp fragment) indicates the genotypes DD, DI, and II (Fig. 1). To minimize errors introduced by possible misreading, a second independent PCR amplification with a primer pair that recognizes the insertion-specific sequence (I allele) was performed in each sample found to have the DD genotype (5a, $5^{\prime}$-TGG GAC CAC AGC GCC CGC CAC TAC-3’; 5b, 5'-TCG CCA GCC CTC CCA TGC CCA TAA-3'). A further control group of 22 samples was also analyzed. Samples with non-concordant results between two observers, or the absence of a PCR product were rejected. Thirty-six results were considered valid for statistical analysis of the ACE polymorphism.

\section{Statistical analysis}

Data were expressed as mean \pm standard deviation or as proportions. Differences between groups (continuous variables) were compared with the student $t$-test. Chi-square analysis was used to evaluate genotype distribution between patient and control groups. Fisher's exact test was used to evaluate allele distribution. Distribution differ significantly $(P<0.05)$ from that predicted by the Hardy-Weinberg equilibrium. $P$ value $<0.05$ was considered statistically significant. Analysis of data was performed SPSS for Windows software (SPSS inc. Chicago, Illinois, Version 7.5).

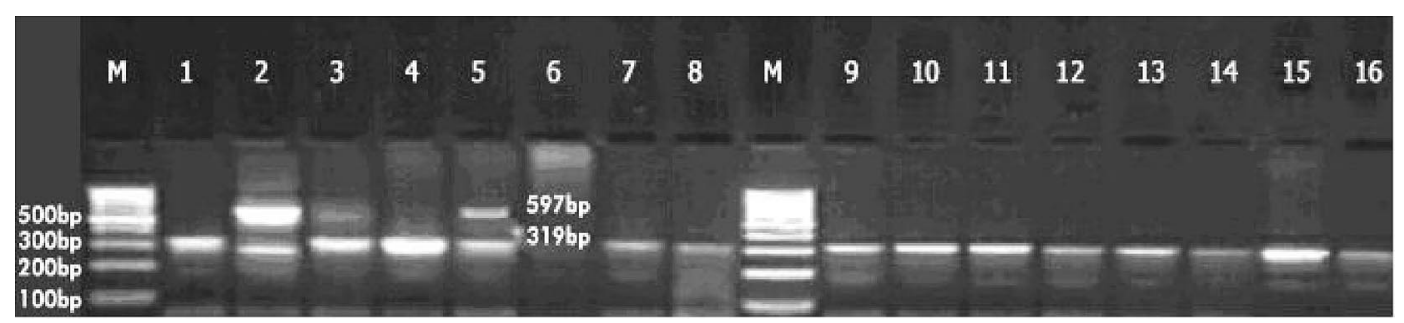

Fig. 1. Determination of ACE Genotypes by PCR Amplification.

The resulting PCR products were separated on $2 \%$ agarose gels with ethidium bromide staining and visualized under ultraviolet light. The presence of 319-bp fragment (D allele) and 597-bp fragment (I allele) indicates the possible genotypes DD or DI and DI or II. Genotypes are illustrated together with a molecular weight marker (lane M). 


\section{Results}

Sixteen patients with AD were eligible for inclusion in the analysis, and 22 patients were included in the control group. Demographic characteristics are shown in Table 1. Mean age was 60.1 years in dissection group. Rate of hypertension was $62 \%$ in dissection group and $59 \%$ control group $(P=0.7)$. Among the patients with acute $\mathrm{AD}$, four patients have been followed up with aortic aneurism (Patient numbers: $3,7,11$ and 13 ).

Table 2 shows individual data of patients in the dissection group. Frequencies of dissection type to DeBakey classification were $43 \%$ (7) for type 1, 31\% (5) for type 2, and 25\% (4) for type 3. Deletion/deletion and DI polymorphisms were shown in 13 and 3 patients, respectively. However, none of patients with AD had II polymorphism.

The genotype distributions and allele frequencies of the ACE D/I polymorphism in dissection and control subjects are shown in Table 3. The frequencies of ACE geno- type were $81 \%$ for DD and $19 \%$ for DI genotypes in dissection groups and $27 \%$ for DD and $41 \%$ for DI genotypes in control group, respectively. A statistically significant difference in the frequency of the homozygous DD genotype was observed between dissection and control groups $(81 \%$ vs. 27\%). The overall proportion of the $\mathrm{D}$ and I allele was 0.91 and 0.09 , respectively, in dissection group and 0.48 and 0.52 in control group. There was a deviation of the observed from the Hardy-Weinberg equilibrium $(P<0.05)$. The frequency of I allele in dissection group was significantly lower in control group $(9.4 \%$ vs. $52.2 \%)$. The frequencies of patients with ACE D allele (DD + ID) was significantly higher in dissection group (100\%) than control $(68 \%)(P<0001)$

\section{Discussion}

Aortic dissection is associated with one of the highest mortality rates of all cardiovascular diseases. The ability to

Table 1. Demographic Characteristics of Patients in Dissection and Control Groups.

\begin{tabular}{lccc}
\hline & $\begin{array}{c}\text { Dissection group } \\
n=16\end{array}$ & $\begin{array}{c}\text { Control group } \\
n=22\end{array}$ & $P$ \\
\hline Age (years) & $60.1 \pm 6.2$ & $60.9 \pm 7.3$ & 0.7 \\
Female $n(\%)$ & $6(38)$ & $8(36)$ & 0.9 \\
BMI $\left(\mathrm{kg} / \mathrm{m}^{2}\right)$ & $30.1 \pm 3.7$ & $30.9 \pm 4.1$ & 0.5 \\
Hypertension $n(\%)$ & $10(62)$ & $13(59)$ & 0.6 \\
Diabetes Mellitus $n(\%)$ & $2(12)$ & $3(14)$ & 0.9 \\
\hline
\end{tabular}

Data expressed mean \pm S.D.; BMI, Body Mass Index; $p<0.05$ accepted as statistically significant.

Table 2. Individual Data of Patients with Aortic Dissection.

\begin{tabular}{|c|c|c|c|c|c|c|}
\hline \multirow{2}{*}{$\begin{array}{l}\text { Patient } \\
\text { no }\end{array}$} & \multirow{2}{*}{ Sex } & \multirow{2}{*}{ Age } & \multirow{2}{*}{ Dissection } & \multicolumn{3}{|c|}{ Polymorphism } \\
\hline & & & & DD & DI & II \\
\hline 1 & $\mathrm{M}$ & 71 & Type II & + & & \\
\hline 2 & $\mathrm{M}$ & 68 & Type II & & + & \\
\hline 3 & $\mathrm{~F}$ & 59 & Type I & & + & \\
\hline 4 & F & 52 & Type I & + & & \\
\hline 5 & $\mathrm{M}$ & 65 & Type I & & + & \\
\hline 6 & $\mathrm{M}$ & 72 & Type II & + & & \\
\hline 7 & M & 64 & Type III & + & & \\
\hline 8 & $\mathrm{~F}$ & 51 & Type III & + & & \\
\hline 9 & $\mathrm{~F}$ & 62 & Type I & + & & \\
\hline 10 & $\mathrm{M}$ & 51 & Type II & + & & \\
\hline 11 & $\mathrm{M}$ & 65 & Type I & + & & \\
\hline 12 & $\mathrm{M}$ & 70 & Type III & + & & \\
\hline 13 & $\mathrm{M}$ & 70 & Type I & + & & \\
\hline 14 & $\mathrm{M}$ & 70 & Type II & + & & \\
\hline 15 & $\mathrm{~F}$ & 71 & Type III & + & & \\
\hline 16 & $\mathrm{~F}$ & 59 & Type I & + & & \\
\hline
\end{tabular}

Dissection types were classified as De Bakey classification. 
Table 3. Genotype Distribution and Allele Frequencies in Dissection and Control Groups.

\begin{tabular}{lcrrrrc}
\hline \multirow{2}{*}{ Groups } & $n$ & \multicolumn{3}{c}{ Genotypes } & $n(\%)$ & \multicolumn{2}{c}{ Frequency alleles $(\%)$} \\
\cline { 3 - 7 } & & DD & DI & II & D & I \\
\hline Dissection & 16 & $13(81)$ & $3(19)$ & $0(0)$ & $29(90.6)$ & $3(9.4)$ \\
Control & 22 & $6(27)$ & $9(41)$ & $7(32)$ & $21(47.7)$ & $23(52.2)$ \\
$X^{2}$ & & & 11.9 & & & $<0.001$ \\
$P$ & & & $<0.001$ & & & \\
Fisher's Exact Test & & & & & & \\
\hline
\end{tabular}

$\mathrm{AD}$, Aorta dissection; $p<0.05$ accepted as statistically significant.

predict, diagnose and treat $\mathrm{AD}$ early in its course is therefore important if morbidity and mortality are to be decreased. Determination of genetic profile of patient may be helpful in predicting patients with AD. In our study, we demonstrated that the ACE DD genotype is significantly higher than the II genotype in patients with AD. This observation may be relevant to clinical practice in a number of ways.

Chronic systemic hypertension is accepted as the most common predisposing factor for AD and is present in 62 to $78 \%$ of patients with dissection (Khan and Nair 2002). Numerous studies have demonstrated a relation between ACE gene polymorphisms and arterial hypertension in different patient populations. In a previous study, the frequencies of the DD, ID, and II ACE genotypes was 39\%, 48\%, and 13 in hypertensive patients and $30 \%, 57 \%$ and $13 \%$ in normotensive subjects (Bedir et al. 1999). These rates highlight the issue of ACE gene polymorphism in hypertensive population in our population. In our study, rates of hypertension were $62 \%$ in patients with $\mathrm{AD}$ and $59 \%$ in the control group ( $P=$ non significant). However, frequencies of DD and DI genotype were $81 \%$ and $19 \%$ in dissection group. Interestingly, we did not find any patients with II genotype in the dissection group, whereas this was present in $32 \%$ of the control group.

Our observations clearly indicate that a majority of patients with AD have an ACE DD gene polymorphism, and they also suggest that ACE gene polymorphism may be a factor related to $\mathrm{AD}$, independent of its relationship with hypertension. Further epidemiologic studies in different patient populations are required to confirm this important relation.

The determination of the genetic profile of non-syndromic AD may contribute to our understanding of the underlying pathophysiology. In our study, approximately 80 percent of subjects in dissection group had DD, and this rate was significantly higher than controls ( $81 \%$ vs. $27 \%$ ). If our results are confirmed by further studies, determination of DD genotype might contribute towards prediction of the development of AD in non-syndromic patients.

The presence of DD genotype or D allele may influence development of $\mathrm{AD}$ via a number of different mechanisms. For example, damage to the intimal and medial layers of the aortic wall can cause aneurysm and dissection in aorta. It is known that ACE activity is higher in patients with D allele, resulting increase in AT II and aldosterone levels in these patients. Increased levels of AT II and aldosterone are atherogenic and have unfavorable effects on vascular system such as cellular apoptosis, lipoprotein peroxidation, vascular smooth muscle proliferation and vascular matrix synthesis (Dzau 1993; Camsari et al. 2003). We suggest that such changes in the vasculature of patients with DD gene polymorphism might result in a predisposition to dissection of the aortic arc. Histological studies examining vascular changes in patients with $\mathrm{AD}$ with and without DD polymorphism may help to confirm this hypothesis.

The proteolytic degradation of aortic wall connective tissue, inflammation and immune responses, oxidative mechanisms, molecular genetics and atherosclerosis of aortic wall are postulated pathogenesis for aortic aneurism and AD (Wassef et al. 2001). These pathophysiologic factors lead to weakening of the aorta's media and cause to higher wall stress, and aortic dilatation (Erbel et al. 2001). Aortic aneurisms eventuate with $\mathrm{AD}$ or rupture in most patients (Erbel et al. 2001). Hence, pathogenesis of aortic aneurism and $\mathrm{AD}$ is closely associated. In this study, four patients with dissection have aortic aneurysm. Further large studies are needed to determinate genetic properties of both aortic aneurism and AD.

The main limitation of our study lies in the limited number of patients examined, which is related to the fact that AD is a very rare disease of the vascular system. Despite its small size, however, we suggest that our study reveals an important relationship between $\mathrm{AD}$ and $\mathrm{ACE}$ gene polymorphism which warrants further investigation. A further limitation of our study is the relation between mortality and ACE gene polymorphism in AD was not investigated. Further survival studies may provide useful clinical information in such patients.

In summary, our data demonstrate that ACE DD gene polymorphism is an associated factor with acute AD. This observation may be important in clinical practice and should be confirmed in further large studies in different patient populations.

\section{References}

Agerholm-Larsen, B., Nordestgaard, B.G. \& Tybjaerg-Hansen, A. (2000) ACE gene polymorphism in cardiovascular disease: 
meta-analyses of small and large studies in whites. Arterioscler. Thromb. Vasc. Biol., 20, 484-492.

Bedir, A., Arik, N., Adam, B., Kilinc, K., Gumus, T. \& Guner, E. (1999) Angiotensin converting enzyme gene polymorphism and activity in Turkish patients with essential hypertension. Am. J. Hypertens., 12, 1038-1043.

Biddinger, A., Rocklin, M., Coselli, J. \& Milewicz, D.M. (1997) Familial thoracic aortic dilatations and dissections: A case control study. J. Vasc. Surg., 25, 506-511.

Boileau, C., Jondeau, G., Mizuguchi, T. \& Matsumoto, N. (2005) Molecular genetics of Marfan syndrome. Curr. Opin. Cardiol., 20, 194-200.

Caglayan, A.O. \& Dundar, M. (2009) Inherited diseases and syndromes leading to aortic aneurysms and dissections. Eur. J. Cardiothorac. Surg., 35, 931-940.

Cambien, F., Poirier, O., Lecerf, L., Evans, A., Cambou, J.P., Arveiler, D., Luc, G., Bard, J.M., Bara, L., Ricard, S., Tiret, L., Amouyel, P., Galas, F.A. \& Soubrier, F. (1992) Deletion polymorphism in the gene for angiotensin-converting enzyme is a potent risk factor for myocardial infarction. Nature, 359, 641-644.

Camsari, A., Pekdemir, H., Cicek, D., Polat, G., Akkus, M.N., Doven, O., Cin, V.G., Katircibasi, T. \& Parmaksiz, T. (2003) Endothelin-1 and nitric oxide concentrations and their response to exercise in patients with slow coronary flow. Circ. J., 67, 1022-1028.

De Bakey, M.E., Henly, W.S., Cooley, D.A., Morris, G.C. Jr., Crawford, E.S. \& Beall, A.C. (1965) Surgical management of dissecting aneurysms of the aorta. J. Thorac. Cardiovasc. Surg., 49, 130-149.

De Bakey, M.E., McCollum, C.H., Crawford, E.S., Morris, G.C. Jr., Howell, J., Noon, G.P. \& Lawrie, G. (1982) Dissection and dissecting aneurysms of the aorta: Twenty-year follow-up of five hundred twenty-seven patients treated surgically. Surgery, 92, 1118-1134.

Dzau, V.J. (1993) Tissue renin-angiotensin system in myocardial hypertrophy and failure. Arch. Intern. Med., 153, 937-942.

Ehlers, M.R.W. \& Riordan, J.F. (1989) Angiotensin converting enzyme: new concepts concerning its biological role. Biochemistry, 28, 5311-5318.

Erbel, R., Alfonso, F., Boileau, C., Dirsch, O., Eber, B., Haverich, A., Rakowski, H., Struyven, J., Radegran, K., Sechtem, U., Taylor, J., Zollikofer, C., Klein, W.W., Mulder, B. \& Providencia, L.A.; Task Force on Aortic Dissection, European Society of Cardiology. (2001) Diagnosis and management of aortic dissection. Eur. Heart J., 22, 1642-1681.

Erdos, E.G. (1990) Angiotensin I converting enzyme and the changes in our concepts through the years. Hypertension, 16, 363-370.

Esther, C.R., Marino, E.M., Howard, T.E., Machaud, A., Corvol, P., Capecchi, M.R. \& Bernstein, K.E. (1997) The critical role of tissue angiotensin-converting enzyme as revealed by gene targeting in mice. J. Clin. Invest., 99, 2375-2385.

Hagan, P.G., Nienaber, C.A., Isselbacher, E.M., Bruckman, D., Karavite, D.J., Russman, P.L., Evangelista, A., Fattori, R., Suzuki, T., Oh, J.K., Moore, A.G., Malouf, J.F., Pape, L.A.,
Gaca, C., Sechtem, U., Lenferink, S., Deutsch, H.J., Diedrichs, H., Marcos, Y, Robles, J., Llovet, A., Gilon, D., Das, S.K., Armstrong, W.F., Deeb, G.M. \& Eagle, K.A. (2000) The International Registry of Acute Aortic Dissection (IRAD): new insights into an old disease. JAMA, 283, 897-903.

Hubert, C.D., Houot, A.M., Corvol, P. \& Soubrier, F. (1991) Structure of the angiotensin I-converting enzyme gene. J. Biol. Chem., 266, 15377-15383.

Jalil, J.E., Piddo, A.M., Cordova, S., Chamorro, G., Braun, S., Jalil, R., Vega, J., Jadue', P.L., Lavandero, S. \& Lastra, P. (1999) Prevalence of the angiotensin I converting enzyme insertion/ deletion polymorphism, plasma angiotensin converting enzyme activity, and left ventricular mass in a normotensive Chilean population. Am. J. Hypertens., 12, 697-704.

Khan, I.A. \& Nair, C.K. (2002) Clinical, diagnostic, and management perspectives of aortic dissection. Chest, 122, 311-328.

Larson, E.W. \& Edwards, W.D. (1984) Risk factors for aortic dissection: a necropsy study of 161 cases. Am. J. Cardiol., 53, 849-855

Lindpaintner, K., Pfeffer, M.A., Kreutz, R., Stampfer, M.J., Grodstein, F., LaMotte, F., Buring, J. \& Hennekens, C.H. (1995) A prosoective evaluation of an angiotensin-convertingenzyme gene polymorphism and the risk of ischemic heart disease. N. Engl. J. Med., 332, 706-711.

Matsubara, M. (2000) Genetic determination of human essential hypertension. Tohoku J. Exp. Med., 192, 19-33

Rigat, B., Hubert, C., Alhenc-Gelas, F., Cambien, F., Corvol, P. \& Soubrier, F. (1990) An insertion/deletion polymorphism of the human angiotensin converting enzyme gene accounting for half the variance of serum enzyme levels. J. Clin. Invest., 86, 1343-1346.

Robinson, P.N., Arteaga-Solis, E., Baldock, C., Collod-Béroud, G., Booms, P., De Paepe, A., Dietz, HC., Guo, G., Handford, PA. Judge, D.P., Kielty, C.M., Loeys, B., Milewicz, D.M., Ney, A., Ramirez, F., Reinhardt, D.P., Tiedemann, K., Whiteman, P. \& Godfrey, M. (2006) The molecular genetics of Marfan syndrome and related disorders. J. Med. Genet., 43, 769-787.

Tsutaya, S., Kitaya, H., Saito, Y., Nakata, S., Takamatsu, H. \& Yasujima, M. (1997) Angiotensin converting enzyme gene polymorphism and its enzyme activity in serum in young Japanese females. Tohoku J. Exp. Med., 182, 151-155.

Uemura, K., Nakura, J., Kohara, K. \& Miki, T. (2000) Association of ACE I/D polymorphism with cardiovascular risk factors. Hum. Genet., 107, 239-242

Wassef, M., Baxter, B.T., Chisholm, R.L., Dalman, R.L., Fillinger, M.F., Heinecke, J., Humphrey, J.D., Kuivaniemi, H., Parks, W.C., Pearce, W.H., Platsoucas, C.D., Sukhova, G.K., Thompson, R.W., Tilson, M.D. \& Zarins, C.K. (2001) Pathogenesis of abdominal aortic aneurysms: a multidisciplinary research program supported by the National Heart, Lung, and Blood Institute. J. Vasc. Surg., 34, 730-738

World Health Organization, International Society of Hypertension Writing Group. (2003) World Health Organization (WHO)/ International Society of Hypertension (ISH) statement on management of hypertension. J. Hypertens., 21, 1983-1992. 